\title{
(9)
}

\section{Impact of Poverty and Population Increase on Environmental Degradation: A Comparative Study of Pakistan and India}

\author{
Sher Ali ${ }^{\text {a }}$, Bibi Aisha Sadiqa ${ }^{\text {b }}$, Sajjad Ali ${ }^{c}$, Shabana Parveen ${ }^{\text {d }}$ \\ ${ }^{a}$ Assistant Prof. Department of Economics, Islamia College, Peshawar, Pakistan \\ Email: drali@icp.edu.pk \\ ${ }^{\mathrm{b}}$ Assistant Professor, Department of Economics, Hazara University Manshra, Pakistan \\ Email: agrieco24@yahoo.com \\ ${ }^{\mathrm{c}}$ Lecturer, Higher Education department, and PhD scholar, University of Peshawar, Pakistan \\ Email: sajjadgeography@gmail.com \\ ${ }^{\mathrm{d}}$ Assistant Professor, Department of Economics, Hazara University, Mansehra, Pakistan \\ Email: shabana_economist@yahoo.com
}

\begin{tabular}{|c|c|}
\hline ARTICLE DETAILS & \multirow{5}{*}{$\begin{array}{l}\text { ABSTRACT } \\
\text { This study is devoted to elucidating the impact of poverty and } \\
\text { population increase on air pollution (CO2-emission) in the two most } \\
\text { populous countries of South Asia i.e. Pakistan and India. Annual time } \\
\text { series data for the period of 199o-2018 are used to examine the said } \\
\text { impact. To estimate the desired impact Autoregressive Distributed Lags }\end{array}$} \\
\hline History: & \\
\hline d 29 Aug 2020 & \\
\hline Available Online 30 Sep 2020 & \\
\hline Кеум & \\
\hline ize, Environme & \multirow{6}{*}{$\begin{array}{l}\text { (ARDL) technique is used. It is observed that } \mathrm{CO} 2 \text { emission is } \\
\text { significantly determined by population increase and poverty in case of } \\
\text { India. In the case of Pakistan population increase significantly affect } \mathrm{CO} 2 \\
\text { emission in both the short run and long run, while poverty don not } \\
\text { contributed significantly in the long run. Industrial production if found } \\
\text { positive and statistically significant in both the runs. Stability of the } \\
\text { model and other diagnostic tests are also employed not serious } \\
\text { econometric problems are repowered. It is suggested on the bases of } \\
\text { results that serious steps should be taken to reduce environmental } \\
\text { pollution by reducing population increase and poverty. Industrial } \\
\text { production also contributed to air pollution therefore industrial policies } \\
\text { are also needed to be employed to reduce Air pollution. }\end{array}$} \\
\hline & \\
\hline & \\
\hline Q56 & \\
\hline DOI: & \\
\hline & \\
\hline
\end{tabular}

(C) 2020 The authors. Published by SPCRD Global Publishing. This is an open access article under the Creative Commons Attribution-

NonCommercial 4.0

Corresponding author's email address: drali@icp.edu.pk

\section{Introduction}

The word Environment is taken from French word "Environ" which means "surrounding". Surrounding consist of two factors including biotic and abiotic. In biotic factors contains Animal, human beings, microbes and animals etc., while abiotic factors includes Air, light, soil and water etc. According 
to the Merriam-Webster Dictionary the word Environment is defined as; the complex of physical, chemical, and biotic factors (such as climate, soil, and living things) that act upon an organism or an ecological community and ultimately determine its form and survival. Environment means that which envelop the earth and consist of entire ecosystem or the region in which everything exist (Gana \& Toba, 2015). The affecting of organism by any condition which is surrounding us is known as Environment (Davis, 1989). According to the definition of Last (2011) Environment is any things which outside the human crowd. Oxford dictionary defined the word pollution as; the undesirable modification of clothing, foods, soil and water. Disequilibrium condition from equilibrium condition in any system is called pollution (Singh, 1991). Environmental pollution is defined as the defect of biological and physical mechanism of the world system which harmfully affects the environmental process (Muralikrishna \& Manickam, 2017).

The planet of the contemporary world faced many serious challenges which are directly or indirectly connected to human lives. And these serious challenges affect human lives adversely. Environmental degradation is the most important issues. Environmental pollution is not only the problem of developing countries it is a serious issue with developed world too. Many factors are reported which cause environmental degradation i.e. Population growth, Economic growth, Urbanization, Poverty, over production, per capita Consumption, uses of Energy and increasing the intensity of transportation etc (Ehrlich \& Holdren, 1972; Shi, 2001)). The first theoretical consensus was presented by Maltus in 1797 that increase in population growth put pressure on a limited natural resource. It is observed that Environmental pollution in developing is due to high pollution and poverty, while industrialization and high mass consumption are the key factors contributed environmental pollution in developed world. Ehrlich and Holdren (1972) observed that the number of people living in any specific geographical area and the use of sophisticated technologies. Bongarrts (1992), Dietz and Rosa (1994) and Engelman (1998) are of the view that population increase is the main source of $\mathrm{CO}_{2}$ emission. Current research studies are also of the view that increasing $\mathrm{CO}_{2}$ emission buildup of Greenhouse effect, which cause Global warming (Watson et al., 1996; Mir \& Storm, 2016).

World population reached to 7.7 billion with a growth rate of 2.51 in 2018 . The bulk of new addition to the world's total population put pressure on natural resources. With the increase in population the desire for food, health and shelter increases as well. Such increase in desire cause increase in aggregate consumption, which may cause environmental degradation. It means that population increase is directly or indirectly involve in the emergence of environmental damage. Mostly developing countries are responsible for the mass increase in population; and these countries mostly relying on primary sector. Therefore, they use land reforms (production of new land for agricultural purpose), different kinds of agrochemicals and sophisticated technology for the increase in production. Moreover, the intensive transformation of agricultural sector to industrial sector also contributes its part in the expansion of pollution. Developing countries has also the experience of over productivity, deforestation, high rate of poverty, having weak institutions (corruptions) and unplanned urbanization. The mid of the 2oth century exaggerates the use of industrial sector for development and become the slogan of the time. But with the emergence of the 21st century huge environmental degradation was experienced and massive adverse effects are observed. Therefore, a slogan begins with a new horizon of sustainability (maximum gains with minimum hazards).

Literature reported many factors economic and non-economic activities caused environmental pollution. According to Birdsall (1992) high Population growth could be a treat and contribute to $\mathrm{CO}_{2}$ emission by two different ways. Firstly, growing population leads to increase the demand for more goods and services to meet the growing needs. The intensity in production put burden fixed existing resources (Environment). Secondly, along with the increase in production there is an increase in 
consumption. Increasing consumption also cause environmental pollution. Population increase affect environment structure adversely both directly and indirectly (Thomes, 1989). Mass population means massive needs intensive use of natural resources: exert pressure on agricultural land and forests to meet food and shelter need leads to deforestation (Ahmad et al., 2005). Developing countries are of the nature high rate of population cause poverty (Editorial 1998).

Most of the searchers founded two ways relationship between economic growth and environmental pollution. In the first phase of economic growth environment affected adversly i.e. with the increase in production there is an increase in $\mathrm{CO}_{2}$ emission, but latter on the increase in economic growth there is a decrease in $\mathrm{CO}_{2}$ emission. The first phase of economic growth is associated with Structural changes and the second phase is with Technical changes (Shafic and Bandyopadhyay, 1992; De Bruyn et al., 1998; Dinda et al., 2000; Hettige et al., 2000). Structural change is that type in which production process shift from pollution intensive industry to informative base industry, in the result less pollution will create (Panayotou, 2003). While the technical change includes the betterment of technology in the production process of industries, in the results the production would increase and the environmental pollution would decrease. The improvement in environmental quality or better environment can be achieved by advancing the technological mode of productions (Bruy, 1997; Xiaoli \& chatterjee. 1997). The Industrial sector usually regarded as more pollution intensive then services sectors (Neumayer, 2003). In developing countries the process of industrialization is totally based on pollution, because the most polluted industries of the world are presents in developing countries (Perrings \& Ansuategi, 2000). Research plays an important role in economic growth and technological advancement in a country (Nadiri, 1993). According to De Bruyn et al (1998) environmental deprivation may have decreased by bringing structural and technological changes not by high economic growth.

South Asia is the most vulnerable region to environmental degradation and climate changes in the world. India and Pakistan are the most populous and large economies in South Asia. They are also growing at faster rates than the others in the region. The high economic growth rates could be assured by the intensive use of energy and many structural changes in both countries. Both the countries are facing huge number of population in the stat of poverty. Therefore this study is very important to highlight the impact of population increase and poverty on $\mathrm{CO}_{2}$ emission (Environmental Degradation/Environmental Pollution).

\section{Research Methodology}

\subsection{The Model}

To find out the impact of net population increase and poverty on $\mathrm{CO}_{2}$ emission in Pakistan and India this study followed Ullah et al., (2019); Parveen et al., (2020); Masron \& Subramaniam (2019); Kassa \& Delelegn, (2018) in model selection. The model of current study is of the form:

$$
C O_{2 t}=\beta_{t}+\beta_{t} P I_{t}+\beta_{t} P O V_{t}+\beta_{t} I P_{t}+\mu_{t}
$$

Where

$$
\begin{aligned}
& \mathrm{CO}_{2}=\text { Carbon Dioxide Emission } \\
& \mathrm{PI}=\text { Net Increase in Population } \\
& \mathrm{PV}=\text { Poverty } \\
& \mathrm{IP}=\text { Industrial Production } \\
& \mu=\text { Error Term }
\end{aligned}
$$




\subsection{Nature and Time Period of the Data}

To estimate equation (1) for the countries Pakistan and India time series annual data is used for the period of 1990 to 2018 . The time period of the study is enough to use cointegration technique. Data is taken for both the countries from World development Indicator: World Bank website.

\subsection{Econometric Techniques}

This study deals in time series data and time series data have their own problem. One of the most important problem associated with time series data is unit root testing. Therefore, it is worthwhile to test stationarity. For testing of stationarity this study employed AFD test.

\subsection{Estimation Technique}

The selection and employment of suitable technique is based on the outcome of ADF test. ARDL technique is preferred over other co-integration techniques are that it is applicable in case of both mix order and order one. In the process of ARDL the first step is to test the existence of long run relationship and in the second step long run and short are estimated.

\section{Results and Discussions}

To test the stationarity of the data Augmented Dickey Fuller (ADF) test is employed. The outcomes of the unit root test are given in the following Tables In table-1 for Pakistan's economy and fin Table-2 for India's economy.

Table-1: ADF Test Results the Data of Pakistan

\begin{tabular}{|c|l|l|l|l|r|}
\hline \multirow{2}{*}{ Variables } & \multicolumn{2}{|l|}{ Level at 5\% } & \multicolumn{2}{l|}{ First Difference at 5\% } & \\
\cline { 2 - 5 } & $\begin{array}{l}\text { Statistical } \\
\text { value }\end{array}$ & $\begin{array}{l}\text { Critical } \\
\text { value }\end{array}$ & $\begin{array}{l}\text { Statistical } \\
\text { value }\end{array}$ & $\begin{array}{l}\text { Critical } \\
\text { value }\end{array}$ & \multirow{2}{*}{ Outcome } \\
\hline CO2 & -1.062 & -3.028 & -5.081 & -3.028 & $\mathrm{I}(1)$ \\
\hline PI & -0.856 & -3.017 & -4.826 & -3.017 & $\mathrm{I}(1)$ \\
\hline Pov & -0.983 & -3.009 & -4.991 & -3.009 & $\mathrm{I}(1)$ \\
\hline IP & -1.889 & -3.022 & -6.718 & -3.022 & $\mathrm{I}(1)$ \\
\hline
\end{tabular}

It is clear from the outcomes of the ADF test that all the variables i,e, $\mathrm{CO}_{2}$ emission, PI, Pov and IP become stationary after first difference. Therefore, all the variables for Pakistan economy are stationary of Order one I(1) at 5\% level of significance.

Table-2: ADF Test Results the Data of India

\begin{tabular}{|c|c|c|c|c|c|}
\hline \multirow[b]{2}{*}{ Variables } & \multicolumn{2}{|l|}{ At Level } & \multicolumn{2}{|c|}{ At First Difference } & \multirow[b]{2}{*}{ Outcome } \\
\hline & $\begin{array}{l}\text { Statistical } \\
\text { value }\end{array}$ & $\begin{array}{l}\text { Critical } \\
\text { value }\end{array}$ & $\begin{array}{l}\text { Statistical } \\
\text { value }\end{array}$ & $\begin{array}{l}\text { Critical } \\
\text { value }\end{array}$ & \\
\hline $\mathrm{CO}_{2}$ & -1.802 & -3.028 & -6.029 & $-3 \cdot 316$ & $\mathrm{I}(1)$ \\
\hline PI & -1.981 & -3.017 & -6.226 & -3.128 & $\mathrm{I}(1)$ \\
\hline POV & -3.806 & -3.009 & -9.204 & -3.206 & $\mathrm{I}(\mathrm{O})$ \\
\hline IP & -4.849 & -3.022 & -9.881 & -3.225 & $\mathrm{I}(\mathrm{o})$ \\
\hline
\end{tabular}

\section{At $5 \%$ level of significance}

In table-2, it is obvious that the first two variables are i.e. $\mathrm{CO}_{2}$ emission and PI became stationary after first difference while the other two variables i.e. 'Pov' and 'IP' are stationary at level. 
Therefore, it is concluded that variables $\mathrm{CO}_{2}$ emission and PI are of order one I(1) stationary and Variables 'Pov' and 'IP' are of order zero I(o) stationary.

\subsection{Estimation Technique}

After testing the stationarity of the variables, it was confirmed that there is a mixture of the order of integration exists; the best technique to examine the long run association among the variables is ARDL. The joint significance of the F-statistic can confirm the existence of co-integration among the variable. The F statistic results are shown in Table 3.3 for India and in Table 3.4 for Pakistan. The estimated value of the $\mathrm{F}$ statistic in both tables is greater than the upper bounds critical values. It ensures the long run relationship among $\mathrm{CO}_{2}$ emissions per capita, GDP per capita, GDP per capita square, energy consumption per capita and manufacturing value added to GDP, when $\mathrm{CO}_{2}$ emissions per capita was used as dependent variable in case of India and Pakistan for the period of 1971-2015.

Table-3 Bound Test for Pakistan and India

\begin{tabular}{|c|c|c|c|c|}
\hline \multicolumn{3}{|l|}{ Pakistan } & \multirow{2}{*}{\multicolumn{2}{|c|}{$\begin{array}{l}\text { India } \\
E f(P O P, P O V, I P)\end{array}$}} \\
\hline Equation & \multicolumn{2}{|c|}{ Ef(PI, POV , IP) } & & \\
\hline F-statistic & \multicolumn{2}{|c|}{10.006} & \multicolumn{2}{|c|}{5.041} \\
\hline Optimum lag order & \multicolumn{2}{|c|}{$(1,1,1,0,1)$} & $(1,2,1,1,0)$ & \\
\hline Significance Level & Lower Bound & Upper bound & Lower Bounds & Upper Bounds \\
\hline At $1 \%$ & 4.892 & 6.889 & 3.922 & 4.908 \\
\hline At $5 \%$ & 4.150 & $5 \cdot 381$ & 3.518 & 4.012 \\
\hline at10\% & 3.852 & 5.001 & 2.895 & 3.620 \\
\hline
\end{tabular}

The above table-3 shows the value of F-statistic or Bound test for economies of Pakistan and India. F-Statistic's calculated values are compared with critical values. The F-statistic calculated values are 10.006 and 5.041 respectively for Pakistan and India which is greater than the upper bound critical values at $1 \%$ level of significance. Hence, it's concluded that there is existed long run association between the variables under consideration. Here we can say that there is long run association between $\mathrm{CO}_{2}$ emission and net population increase, Poverty and industrial production. The next step is to estimate the values of parameter for both the long run and short runs for the economies of Pakistan and India.

Table-4: Long Run Estimates for Pakistan and India

\begin{tabular}{|l|c|c|}
\hline \multicolumn{3}{|c|}{ Dependent Variable $=\mathbf{C O}_{\mathbf{2}}$ Emission } \\
\hline Variable & Pakistan & India \\
\hline \multirow{3}{*}{ PI } & 0.642 & 0.652 \\
& $(3.238)$ & $(8.252)$ \\
& $\{0.003\}$ & $\{0.000\}$ \\
\hline \multirow{4}{*}{ POV } & 0.344 & 0.287 \\
& $(3.173)$ & $(8.252)$ \\
& $\{0.003\}$ & $\{0.000\}$ \\
\hline \multirow{4}{*}{ C } & 1.661 & 2.165 \\
& $(6.753)$ & $(8.692)$ \\
& $\{0.000\}$ & $\{0.000\}$ \\
\hline & -26.126 & -25.426 \\
& $(-5.734)$ & $(-17.949)$ \\
& $\{0.000\}$ & $0.000\}$ \\
\hline & $\mathrm{R}^{2}=0.719$ & $\mathrm{R}^{2}=0.84$ \\
\hline & Adj $\mathrm{R}^{2}=0.7061$ & $\mathrm{Adj}^{2}=0.809$ \\
\hline & $\mathrm{D}^{2} \mathrm{~W}=2.21$ & $\mathrm{D}^{2} \mathrm{~W}=2.09$ \\
\hline
\end{tabular}


Long run estimates of the models for the economies of Pakistan and India are given in the above Table-4. In column $2^{\text {nd }}$ the estimates are related to Pakistan economy and in column in $3^{\text {rd }}$ the values of coefficient and T-statistic (values presented in parenthesis) and Prob-values (values presented in Brackets i.e. \{\} ) are presented. The coefficient value of net Population increase is 3.238 and 8.252 respectively for Pakistan and India. It is clear from the T-statistic value and Porb-values that net population increase is positive and statistically significant at $5 \%$ level of significance. There is positive relationship between net population increase and $\mathrm{CO}_{2}$ emission. Population increase put pressure on natural resources due to intensively use of the resources adversely affect environment is in line with findings of the study conducted by Mittal \& Mittal (2013).

The coefficients of poverty are 0.344 and 0.287 which shows positive association between poverty and $\mathrm{CO}_{2}$ emission in both the countries. The corresponding values of T-statistic are greater than 1.96 and prob-values are less than 0.05 which shows that the variable statically significantly affect $\mathrm{CO}_{2}$ emission. Hence there is direct significant relationship between poverty and $\mathrm{CO}_{2}$ emission. The findings of the present study are parallel with the findings of the studies conducted by Masron and Subramaniam (2018) and (Boyce 1994) that poverty affect environmental degradations in most of the developing countries. Masron and Subramaniam (2018) examined 50 developing countries in his study.

Now if we see to the coefficient of industrial production which are 1.661 and 2.165 which indicates that there exists a positive connection between industrial production and $\mathrm{CO}_{2}$ emission for Pakistan and India. The T-statistic values are greater than 1.96 and prob-values are less than 0.05 which shows that industrial production and $\mathrm{CO}_{2}$ emission are directly correlated to each other. Therefore it's concluded that if industrial production increases then ultimate increase occur in $\mathrm{CO}_{2}$ emission. Industrial production in the spell of Revolution is the key source of environmental Pollution in the present world (Ahuti, 2015).

Table-5: Short Run Estimates for Pakistan and India

\begin{tabular}{|l|c|c|}
\hline \multicolumn{3}{|c|}{ Dependent Variable $=$ CO2 } \\
\hline Variable & Pakistan & India \\
\hline DPI & 11.311 & 7.576 \\
& $(2.074)$ & $(4.58)$ \\
& $\{0.046\}$ & $\{0.000\}$ \\
\hline DPov & 0.528 & 0.595 \\
& $(1.928)$ & $(4.033)$ \\
& $\{0.063\}$ & $\{0.003\}$ \\
\hline DIP & 0.608 & 1.313 \\
& $(2.267)$ & $(5.612)$ \\
& $\{0.030\}$ & $\{0.000\}$ \\
\hline ECT-1 & -0.663 & -0.552 \\
& $(-5.130)$ & $(-3.417)$ \\
& $\{0.000\}$ & $\{0.006\}$ \\
\hline
\end{tabular}

The Short run estimates for Pakistan and India are given in table 5. The coefficients of net population increase for Pakistan and India 11.311 and 7.576 which indicate that there is positive relationship between net population and $\mathrm{CO}_{2}$ emission. The corresponding $\mathrm{T}$-values are greater than 
1.96 and p-values less than 0.05 which specifies that there found positive and significant association between net population and $\mathrm{CO}_{2}$ emission.

The coefficients of poverty are 0.528 and 0.595 which express direct association between poverty and $\mathrm{CO}_{2}$ emission in both the countries. The corresponding values of T-statistic are greater than 1.96 and p-values are less than 0.05 which indicates that connection between poverty and $\mathrm{CO}_{2}$ emission positively associated with each other.

The coefficient of industrial production is positive which shows that there is positive relation between industrial production and $\mathrm{CO}_{2}$ emission for both countries. From the given table it's also clear that T-statistic values are 2.267 and 5.612 respectively which greater than 1.96 and p-values is less than 0.05 which resulted that industrial production and $\mathrm{CO} 2$ emission are positively statically significant on each other.

The stability of parameters can be checked with the help of a Cumulative Sum (CUSUM) and Cumulative Square Sum (CUSUMSQ) technique. Results of these two tests for India are given in graph (3.9) and (3.10). Graph (3.11) and (3.12) shows the results for Pakistan. Straight lines in both figures for both countries are within the critical lines at 5\% level of significance. It is clear from the tables that the plots are between the two boundary lines that confirm the stability of long run and short run parameters of the model.

Figure-1

CUSUM for Pakistan

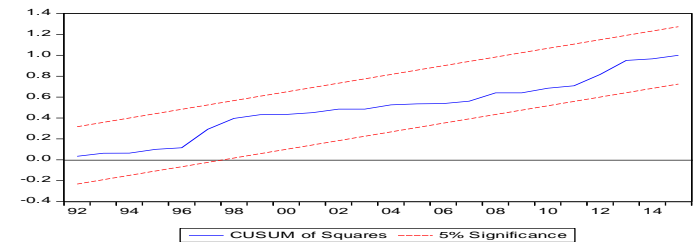

CUSUM for India

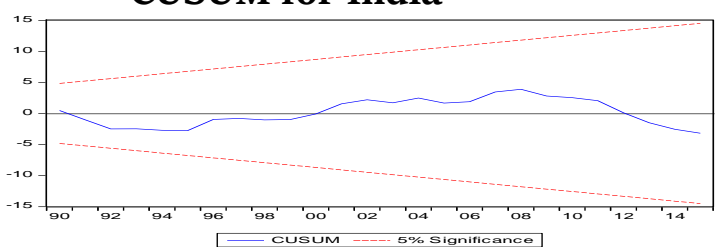

\section{CUSUM Square for Pakistan}

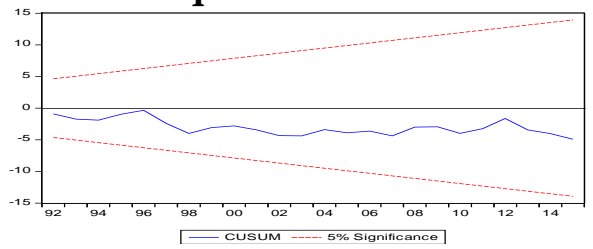

CUSUM Square for India

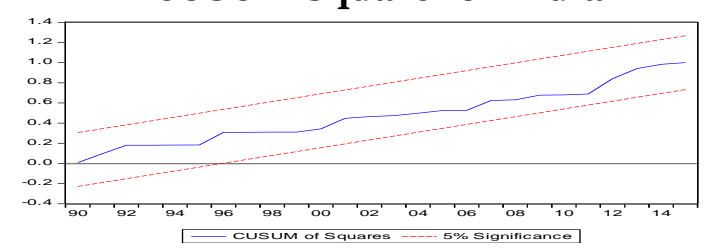

\section{Conclusion and Policy Recommendations}

The aim of the present study is to investigate the impact of Net Population increase and poverty on $\mathrm{CO}_{2}$ emission in the two most populous countries of Asia. i.e. Pakistan and India. Time series is collected from WDI for the period of 1990 to 2018 and put into ARDL framework. It is observed that $\mathrm{CO} 2$ emission is significantly determined by population increase and poverty in case of India. In the case of Pakistan population increase significantly affect $\mathrm{CO}_{2}$ emission in both the short run and long run, while poverty also contributed positively and significantly to $\mathrm{CO}_{2}$ emission in both the short and long runs. Industrial production if found positive and statistically significant in both the runs. Stability of the model and other diagnostic tests are also employed not serious econometric problems are repowered. It is suggested on the bases of results that serious steps should be taken to reduce environmental pollution by reducing population increase and poverty. Industrial production also contributed to air pollution therefore industrial policies are also needed to be employed to reduce Air pollution 


\section{References}

Ahmad, M. H., Azhar, U., Wasti, S. A., Inam, Z., \& Ghani, N., (2005), "Interaction between Population and Environmental Degradation”, The Pakistan Development Review, 44 (4), 1135-1150.

Ansuategi, A., Escapa, M., 2002. Economic growth and greenhouse gas emissions. Ecological Economic 40, 23.37.

Birdsall, N., (1992). "Another look at population and global warming”, (Vol. 1020). World Bank Publications.

De Bruyn, S. M., (1997). Explaining the environmental Kuznets curve: structural change and international agreements in reducing sulphur emissions. Environment and development economics, 2(4), 485-503.

De Bruyn, S. M., vanden Bergh, J. C. J. M., Opschoor, J. B., (1998). Economic growth and emissions: reconsidering the empirical basis of Environmental Kuznets Curves. Ecological Economics 25,161-175.

Dinda, S., (2004). Environmental Kuznets curve hypothesis: a survey. Ecological economics, 49(4), 431455 .

Dinda, S., Coondoo, D., Pal, M., 2000. Air quality and economic growth: anempirical study. Ecological Economics 34,409-423

Ehrlich, P., J. Holdren., (1971). “Impact of population growth”, Science 171, 1212-1217

Gana A. J., \&Toba. A. P., (2015). Environmental Pollution and Sustainability: Journal of Research in Environmental Science and Toxicology (ISSN: 2315-5698) 4(1), 1-9.

Hettige, H., Mani, M.,Wheeler, D., 200o.Industrial pollution in economic development: the Environmental Kuznets Curve revisited. Journal of Development Economics 62,445-476

https://www.merriam-webster.com/dictionary/environment

Kassa, G., Teferi, B., \& Delelegn, N. (2018). The poverty-environment nexus in developing countries: Evidence from Ethiopia: A systematic review. Asian Journal of Agricultural Extension, Economics \& Sociology, 1-13.

Malthus, T. R., \& Flew, A., (1797). An Essay on the Principle of Population: And, A Summary View of the Principle of Population. Edited with an Introd. by Antony Flew. Penguin Books.

Mir, G. U. R., \& Storm, S., (2016). “Carbon Emissions and Economic Growth”, Production-based versus Consumption-based Evidence on Decoupling, Ecological Economics, 32(6), 48-6o.

Nadiri, M. I., (1993). Innovations and technological spillovers (No. W4423). National Bureau of Economic Research.

Neumayer, E., (2003). Are left-wing party strength and corporatism good for the environment? Evidence from panel analysis of air pollution in OECD countries. Ecological economics, 45(2), 203-220.

Panayotou, T., 2003. Economic Growth and the Environment 2003. Economic Survey of Europe: UNECE, vol. no. 2; ([chapter 2]).

Shafic, N., Bandyopadhyay, S., 1992. Economic Growth and Environmental Quality. Time series and Cross Country Evidence. Policy Research Working Paper no. 904, World Development Report 1992, The World Bank.

Shi, A., (2001, August). Population growth and global carbon dioxide emissions. In IUSSP Conference in Brazil/session-sog.

Tajul Ariffin Masron \& Yogeeswari Subramaniam (2019) Does Poverty Cause Environmental Degradation? Evidence from Developing Countries, Journal of Poverty, 23:1, 4464, DOI: 10.1080/10875549.2018.1500969

Watson, R. T., Zinyowera, M. C., \& Moss, R. H., (1996). Climate change 1995. Impacts, adaptations and mitigation of climate change: scientific-technical analyses. 